\title{
Maternal Behavior Regulates Benzodiazepine/GABA Receptor Subunit Expression in Brain Regions Associated with Fear in BALB/C and C57BL/6 Mice
}

\author{
Christian Caldji', Josie Diorio', Hymie Anisman² and Michael J Meaney*,' \\ 'Developmental Neuroendocrinology Laboratory, Douglas Hospital Research Centre, McGill University, Montréal, Canada; ${ }^{2}$ Institute of \\ Neuroscience, Carleton University, Ottawa, Ontario, Canada
}

\begin{abstract}
Inbred strains of mice, such as BALB/CBy] and C57BL/6By], have been used repeatedly to study genotype-phenotype relations. These strains differ on behavioral measures of fear. In novel environments, for example, BALB/c mice are substantially more neophobic than C57BL/6 animals. The benzodiazepine (BZ)/GABA receptor system has been proposed as a regulator of behavioral responses to stress, and $B A L B / C$ and $C 57 B L / 6$ mice differ in $B Z / G A B A_{A}$ receptor binding. In the present study, we found increased $B Z$ receptor levels in C57BL/6 mice in the central and basolateral nuclei of the amygdala as well as the locus coeruleus using either flunitrazepam (nonselective) or zolpidem ( $\alpha$ l subtype selective) as radioligands. Differences in receptor binding were most pronounced in the amygdala and locus coeruleus using $\left[{ }^{3} \mathrm{H}\right]$ zolpidem. C57BL/6 mice showed increased $\alpha$ I mRNA levels in the locus coeuruleus compared to $\mathrm{BALB} / \mathrm{c}$ mice. In addition, $\gamma 2 \mathrm{mRNA}$ expression in BALB/c mice was decreased in the central nucleus of the amygdala to levels that were 2-2.5-fold lower than those of C57BL/6 mice. The results of an adoption study revealed that the biological offspring of C57BL/6 mothers fostered after birth to BALB/c dams showed decreased levels of $\gamma 2 \mathrm{mRNA}$ expression in the central nucleus of the amygdala in comparison to peers fostered to other C57BL/6 mothers (the reverse was found for the biological offspring of BALB/c mothers). In a step-down exploration paradigm, BALB/CByJ mice crossfostered onto a C57BL/6Byj dam expressed reduced anxiety responses. However, among C57BL6ByJ mice, the relatively low levels of anxiety ordinarily evident were not increased when mice of this strain were reared by a BALB/CByJ dam. These preliminary findings suggest that the strain differences in the BZ/GABA $A$ receptor system occur, at least in part, as a function of parental care. Such findings may reflect a mammalian example of an indirect genetic effect mediated by maternal care.

Neuropsychopharmacology (2004) 29, 1344-1352, advance online publication, 7 April 2004; doi: I 0. I038/sj.npp. 1300436
\end{abstract}

Keywords: amygdala; mouse; gene expression; benzodiazepine/GABA $\mathrm{A}_{\mathrm{A}}$ receptor; fear/anxiety

\section{INTRODUCTION}

Inbred strains of mice exhibit substantial differences in phenotype (Lindzey and Thiessen, 1970). The BALB/c and C57BL/6 mouse strains are among the most studied and reveal extensive behavioral differences (Oliverio et al, 1973; Peeler and Nowakowski, 1987; Belzung and Griebel, 2001), especially under the conditions of stress (Anisman et al, 2001). The more neophobic BALB/c strain exhibits greater evidence of fear-related behaviors in the open-field

*Correspondence: MJ Meaney, Developmental Neuroendocrinology Laboratory, Douglas Hospital Research Centre, 6875 Boul. LaSalle, Montreal, Quebec, Canada H4H IR3, Tel: + 51476 I 6I3I ext.3938, Fax: + 514762 3034, E-mail: michael.meaney@mcgill.ca

Received 31 July 2003; revised 05 February 2004; accepted 05 February 2004

Online publication: 16 February 2004 at http://www.acnp.org/citations/ Npp02 I 60403345/default.pdf exploration (Oliverio et al, 1973; Griebel et al, 1993) and the light/dark choice tests (Beuzen and Belzung, 1995) as well as increased hypothalamic-pituitary-adrenal (HPA) responses to a wide range of stressors (Anisman et al, 2001). These variations in behavior are reflected in strain differences in neural systems relevant for the expression of fear, such as the benzodiazepine $(\mathrm{BZ}) / \mathrm{GABA}_{\mathrm{A}}$ receptor complex. Compared with $\mathrm{C} 57 \mathrm{BL} / 6$ animals, $\mathrm{BALB} / \mathrm{c}$ mice show reduced $\mathrm{BZ}$ binding in receptor assays as measured using $\left[{ }^{3} \mathrm{H}\right]$ flunitrazepam or $\left[{ }^{3} \mathrm{H}\right]$ diazepam (Robertson, 1979; Chapoutier et al, 1991). Such differences in receptor density are associated with differences in $\mathrm{BZ} / \mathrm{GABA}_{\mathrm{A}}$ receptor pharmacology. B-carboline-3-carboxylate (B-CCM), a benzodiazepine inverse agonist, results in a higher vulnerability to convulsions in $\mathrm{BALB} / \mathrm{c}$ mice compared to $\mathrm{C} 57 \mathrm{BL} / 6$ (Desforges et al, 1989). Moreover, diazepam-induced potentiation of GABA-mediated chloride influx is reduced in $\mathrm{BALB} / \mathrm{c}$ compared to $\mathrm{C} 57 \mathrm{BL} / 6$ mice (Mihic et al, 1992). 
The results of an in vitro receptor autoradiography study using $\left[{ }^{3} \mathrm{H}\right]$ diazepam revealed a striking difference between $\mathrm{C} 57$ and $\mathrm{BALB} / \mathrm{c}$ mice, with dramatically reduced $\mathrm{BZ}$ binding in the $\mathrm{BALB} / \mathrm{c}$ animals that was largely restricted to the central nucleus of the amygdala (Hode et al, 2000), a region known to mediate fear-related behavior (for a review, see Rosen and Shulkin, 1998). The amygdala is also a critical site of action for the anxiolytic effects of $\mathrm{BZ}$ receptor agonists. Studies in humans support the idea that alterations in the $\mathrm{GABA}_{\mathrm{A}} / \mathrm{BZ}$ receptor complex might form the basis of a vulnerability to anxiety disorders (for a review, see Gorman et al, 2000).

Not surprisingly, these findings have spawned efforts to identify the relevant genomic variation underlying the reliable differences in phenotype between $\mathrm{BALB} / \mathrm{c}$ and $\mathrm{C} 57$ mice. However, recent findings from embryo-transfer experiments suggest a considerable epigenetic influence on the development of fear behavior in the BALB/c mice (Francis et al, 2002). Such influences may not be restricted to the prenatal period. There are considerable differences in the maternal behavior of $\mathrm{BALB} / \mathrm{c}$ and $\mathrm{C} 57 \mathrm{BL} / 6$ mice (Zaharia et al, 1996); C57BL/6 mothers lick/groom their pups more frequently than $\mathrm{BALB} / \mathrm{c}$ mothers (Anisman et al, 2001). Crossfostering BALB/c pups onto $\mathrm{C} 57 \mathrm{BL} / 6$ mothers shortly after birth markedly reduces behavioral differences between the strains (Zaharia et al, 1996). In the rat, differences in maternal licking/grooming are associated with individual differences in $\mathrm{BZ} / \mathrm{GABA}_{\mathrm{A}}$ receptor subunit expression (Caldji et al, 2003) and fearfulness in response to novelty (Caldji et al, 1998). The adult offspring of high licking/grooming-arched-back nursing (LG-ABN) mothers show reduced behavioral responses to novelty and increased $\mathrm{BZ}$ receptor binding. Interestingly, the difference in $\mathrm{BZ}$ receptor binding is most pronounced in the amygdala (Caldji et al, 1998). Crossfostering the biological offspring of low-to-high LG-ABN mothers to high LG-ABN dams on the day of birth reverses the pattern of stress reactivity that is characteristic of the normal offspring of low LG-ABN mothers (Francis et al, 1999) as well as the differences in $\mathrm{BZ} / \mathrm{GABA}_{\mathrm{A}}$ receptor binding (Caldji et al, 2003).

The effect of maternal care on the development of the BZ/ $\mathrm{GABA}_{\mathrm{A}}$ receptor complex is associated with alterations in $\mathrm{GABA}_{\mathrm{A}}$ receptor subunit expression. The $\mathrm{GABA}_{\mathrm{A}}$ receptor complex in the rat forebrain, which often includes a 'BZ' binding site, is commonly arranged in a pentameric structure comprised of $\alpha, \beta$, and $\gamma$ subunits, in the form of two $\alpha$, two $\beta$, and one $\gamma$ subunit, or two $\alpha$, one $\beta$, and two $\gamma$ subunits (Barnard et al, 1988; Sieghart, 1995; McKernan and Whiting, 1997; Mehta and Ticku, 1999). The presence of a functional $\mathrm{BZ}$ site on the $\mathrm{GABA}_{\mathrm{A}}$ receptor complex is dependent on the presence of $\alpha$ and $\gamma$ subunits. In the rat, maternal care significantly alters the expression of the $\alpha 1$ as well as both the $\gamma 1$ and $\gamma 2$ subunits in the amygdala, and the effects are reversed with crossfostering (Caldji et al, 2003). Taken together with the data on strain differences in maternal care, these findings suggest that differences in the $\mathrm{BZ} \mathrm{GABA}_{\mathrm{A}}$ receptor complex between $\mathrm{BALB} / \mathrm{c}$ and $\mathrm{C} 57$ mice might emerge, at least in part, as a function of strain differences in mother-pup interactions during postnatal life, and therefore to a nongenomic mode of inheritance.

\section{MATERIALS AND METHODS}

\section{Animals}

Male/female BALB/cByJ and C57BL/6ByJ adult mice (Jackson Laboratories, Bar Harbor, ME) were maintained on a 12:12 light:dark schedule (lights on at 0800) with free access to food and water. For breeding, females and males of both species were housed in the ratio of $2: 1$. Dams were removed from breeding cages when visibly pregnant (approximately 12-14 days of gestation) and individually housed. Mouse pups were weaned at 22 days of age and housed with their siblings in cages of three to five mice. All procedures were performed according to guidelines developed by the Canadian Council on Animal Care with protocols approved by the Carleton and McGill Universities Committee on Animal Care. All experiments were performed by individuals unaware of the developmental history of the animals.

\section{Adoption Study}

Crossfostering was performed within $6 \mathrm{~h}$ following the birth of the last pup and completed within $15 \mathrm{~min}$ of having originally disturbed the litters. Pups born to $\mathrm{BALB} / \mathrm{C}$ mothers were crossfostered onto either other $B A L B / C$ mothers (B-B) or C57BL/6 mothers (B-C57). Likewise, pups born to $\mathrm{C} 57 \mathrm{BL} / 6$ mothers were crossfostered onto either other C57BL/6 mothers (C57-C57) or low BALB/c mothers (C57-B). As we have observed that both BALB/cByJ and C57BL/6ByJ will care for their own pups (defined in terms of their LG-ABN) as readily as they care for fostered pups (data not shown), the adoption study was performed so that whole litters of mice were crossfostered. Thus, although fostering entire litters has been reported to disturb maternal behaviors (Maccari et al, 1995), such an outcome was not observed among the BALB/cByJ or C57BL/6ByJ mice.

\section{Receptor Autoradiography}

For all experiments, brains were obtained from male adult (between 120 and 140 days of age) offspring of $\mathrm{BALB} / \mathrm{c}$ and C57BL/6 mothers ( $n=5-6 /$ group) by rapid decapitation less than 1 min following removal from the home cage. Brains were quickly removed, frozen in $-70^{\circ} \mathrm{C}$ isopentane and stored at $-80^{\circ} \mathrm{C}$. Brains were sectioned in the coronal plane at $15 \mu \mathrm{M}$ and sections were thaw-mounted onto gel-coated slides, which were then stored at $-80^{\circ} \mathrm{C}$ until the time of assay.

Nonselective BZ receptor binding (for $\alpha 1, \alpha 2, \alpha 3, \alpha 5$ subtypes, previously known as type II) was examined using a procedure described by Bureau and Olsen (1993). Slides were thawed and preincubated in assay buffer $(0.17 \mathrm{M}$ Tris$\mathrm{HCl}, \mathrm{pH}$ 7.4) for $30 \mathrm{~min}$ at $4^{\circ} \mathrm{C}$. The slides were then incubated with a saturating $0.5 \mathrm{nM}$ concentration of $\left[{ }^{3} \mathrm{H}\right]$ flunitrazepam $(84.5 \mathrm{Ci} / \mathrm{mmol}$, New England Nuclear, Boston, MA) in assay buffer for $60 \mathrm{~min}$ at $4^{\circ} \mathrm{C}$. Nonspecific, background binding was determined in parallel sections using $1 \mu \mathrm{M}$ clonazepam. Post-assay washes $(2 \times 30 \mathrm{~s})$ were performed using assay buffer. The sections were left to dry overnight and were then apposed to tritium-sensitive Ultrafilm (Amersham Canada Inc., Montréal, Canada) along with $\left[{ }^{3} \mathrm{H}\right]$ microscales for 14 days. 
BZ $\alpha 1$-selective receptor binding (previously known as type I) was quantified using $\left[{ }^{3} \mathrm{H}\right]$ zolpidem $(50.8 \mathrm{Ci} / \mathrm{mmol}$, New England Nuclear) following the procedures described in Ruano et al (1993). Slides were thawed and preincubated in $50 \mathrm{mM}$ Tris- $\mathrm{HCl}$ assay buffer $(120 \mathrm{mM} \mathrm{NaCl}, 5 \mathrm{mM} \mathrm{KCl}$, $\mathrm{pH}$ 7.4) for $30 \mathrm{~min}$ at room temperature. Sections were then incubated in assay buffer containing a saturating $5 \mathrm{nM}$ concentration of $\left[{ }^{3} \mathrm{H}\right]$ zolpidem $(5 \mathrm{nM})$ for $30 \mathrm{~min}$ at $4{ }^{\circ} \mathrm{C}$. Nonspecific binding was determined in parallel sections incubated with buffer containing $50 \mu \mathrm{M}$ of cold zolpidem (purchased from RBI, Natick, MA). Sections were then washed $(2 \times 3 \mathrm{~min})$ in ice-cold assay buffer, rinsed in cold, distilled water and dried rapidly under a stream of cold air. Autoradiograms were generated by apposing slides to tritium-sensitive Ultrafilm with the appropriate $\left[{ }^{3} \mathrm{H}\right]$ microscales for a period of 14 days, a period that provided for linearity of microscales and maximal binding.

Autoradiograms were analyzed by obtaining optical densities (expressed as mean \pm SEM in $\mathrm{fmol} / \mathrm{mg}$ protein) determined by computer-assisted densitometry using an MCID image analysis system (Imaging Research Inc., St Catherines, Ontario, Canada) and low-activity tritium standards using the rat brain atlas of Franklin and Paxinos (1997). There were 3-4 sections per region used in the analysis for each animal and the mean from these values was then used in the statistical analysis.

\section{In Situ Hybridization}

Brains were obtained from adult male animals by rapid decapitation shortly $(<20 \mathrm{~s})$ following the removal of the animal from the home cage. Brains were frozen in isopentane maintained on dry ice and $15 \mu \mathrm{M}$ coronal sections were prepared under RNase-free conditions and stored at $-80^{\circ} \mathrm{C}$. In preparation for the hybridization experiments, sections were prefixed in a $4 \%$ paraformaldehyde solution for $10 \mathrm{~min}$. Sections were then washed in $2 \times$ SSC buffer $(2 \times 5 \mathrm{~min})$ and in $0.25 \%$ acetic anhydride and $0.1 \mathrm{M}$ triethanolamine solution $(\mathrm{pH} 8.0 ; 1 \times 10 \mathrm{~min})$. Sections were then dehydrated using a $50-100 \%$ ethanol gradient, placed in chloroform for $10 \mathrm{~min}$, followed by rehydration in $95 \%$ ethanol. Sections were then incubated overnight at $37^{\circ} \mathrm{C}$ with $75 \mu \mathrm{l} /$ section of hybridization buffer containing $50 \%$ dionized formamide, $10 \mathrm{mM}$ dithiothreitol, $10 \mathrm{mM}$ Tris ( $\mathrm{pH} 7.5$ ), $600 \mathrm{mM}$ sodium chloride, $1 \mathrm{mM}$ EDTA, $10 \%$ dextran sulfate, $1 \times$ Denhardt's solution, $100 \mu \mathrm{g}$ salmon sperm DNA, $100 \mu \mathrm{g} / \mathrm{ml}$ yeast tRNA, with $1 \times 10^{6}$ CPM ${ }^{35}$ S-ddATP-labelled oligonucleotide probe. Oligonucleotide probes $\left(\beta 1: 5^{\prime} \ldots\right.$ GGG GTC ACC CCT GGC TAA GTT AGG GGT ATA GCT GGT TGC TGT AGG ... $3^{\prime} ; \gamma 2: 5^{\prime}$ ... GTC ATA GCC ATA TTC TTC ATC CCT CTC TTG AAG GTG GGT GGC ... 3' $3^{\prime}$ (Wisden et al, 1992) were synthesized (Beckman 1000 DNA Synthesizer, Beckman, USA) and labelled using a DNA $3^{\prime}$-end-labelling kit (Boehringer Mannheim, USA). Note, the $\gamma 2$ oligonucleotide sequence used in this study recognizes both $\gamma 2 \mathrm{~L}$ and $\gamma 2 \mathrm{~S}$ variants of the $\gamma 2$ subunit. Preliminary studies using a scrambled version of the $\alpha 1$ and $\gamma 2$ probes yielded no specific signal on brain sections (data not shown). Following hybridization, slides were washed for $4 \times 30 \mathrm{~min}$ in $1 \times \mathrm{SSC}$ at $55^{\circ} \mathrm{C}$, rinsed briefly in water, dried and apposed to Hyperfilm for 21 days along with sections of ${ }^{35} \mathrm{~S}$-labelled standards prepared with known amounts of ${ }^{35} \mathrm{~S}$ in a brain paste. The hybridization signal within various brain regions was quantified using densitometry with an image analysis system (MCID, St Catherines, Ontario, Canada). The data are presented as arbitrary optical density (absorbance) units following correction for background. The anatomical level of analysis was verified using the rat brain atlas of Franklin and Paxinos (1997) with Nissl staining of sections following autoradiography.

\section{Behavioral Testing}

While numerous tests of anxiety are available that differentiate $\mathrm{C} 57 \mathrm{BL} / 6 \mathrm{ByJ}$ and $\mathrm{BALB} / \mathrm{cByJ}$ mice, the stepdown exploration paradigm is particularly effective. In this paradigm, mice are placed on a small platform at the center of an elevated open field, and the latency to place two or four legs off the platform is measured (Anisman et al, 2001; Sakic et al, 1994). Ordinarily, BALB/cByJ mice are reluctant to step off the platform (essentially a home base) and explore the remainder of the open field, whereas C57BL/ $6 \mathrm{ByJ}$ do so readily; the effect is eliminated with diazepam (Anisman et al, 2001).

Mice ( $\sim 70$ days of age) comprised BALB/cByJ mice raised by a BALB/cByJ $(n=14)$ or a C57BL/6ByJ dam $(n=16)$, or $\mathrm{C} 57 \mathrm{~B} / 6 \mathrm{ByJ}$ mice raised by the same strain $(n=19)$ or a BALB/cByJ $(n=21)$ dam. Mice were placed on a platform $(12.5 \times 8.50 \times 2 \mathrm{~cm})$ situated at the center of a $80 \times 60 \mathrm{~cm}$ table-top located within a dimly lit room, and the latency to step down was monitored. The platform was covered with a thin removable, black rubber sleeve that allowed the animal to grip the surface. To avoid the influence of urine or other odors, the sleeve was changed for each animal. Mice were gently placed on the platform, and the latencies to stretch attend (mice remain fully on the platform, but extend their head body, only to withdraw again), place the two forelegs on the table-top, and place all four legs on the table-top were recorded. If a mouse did not step off the platform within $300 \mathrm{~s}$, the trial was terminated. Mice received three such trials at $1 \mathrm{~min}$ intervals between trials. Even though the platform was quite low, highly anxious mice ordinarily remain on the platform for extended periods, whereas less anxious animals step off and explore.

\section{Statistical Analysis}

The data were analyzed using a two-way (Group $\times$ Region) analysis of variance with Tukey post hoc tests where appropriate.

\section{RESULTS}

\section{Benzodiazepine Receptor Binding}

There was a significant Group and Group $\times$ Region interaction effect $\left(\mathrm{F}_{(9,54)}=2.91 ; p<0.01\right)$ for $\left[{ }^{3} \mathrm{H}\right]$ flunitrazepam binding (Figure 1). Post hoc analysis revealed significantly increased central BZ receptor levels in C57BL/6 mice in the central, basolateral, and lateral nuclei of the amygdala. There were no significant group differences found in the medial prefrontal cortex, the hippocampus, or the locus 
$\mathrm{BALB} / \mathrm{C}$

$\mathrm{C} 57 \mathrm{BL} / 6$

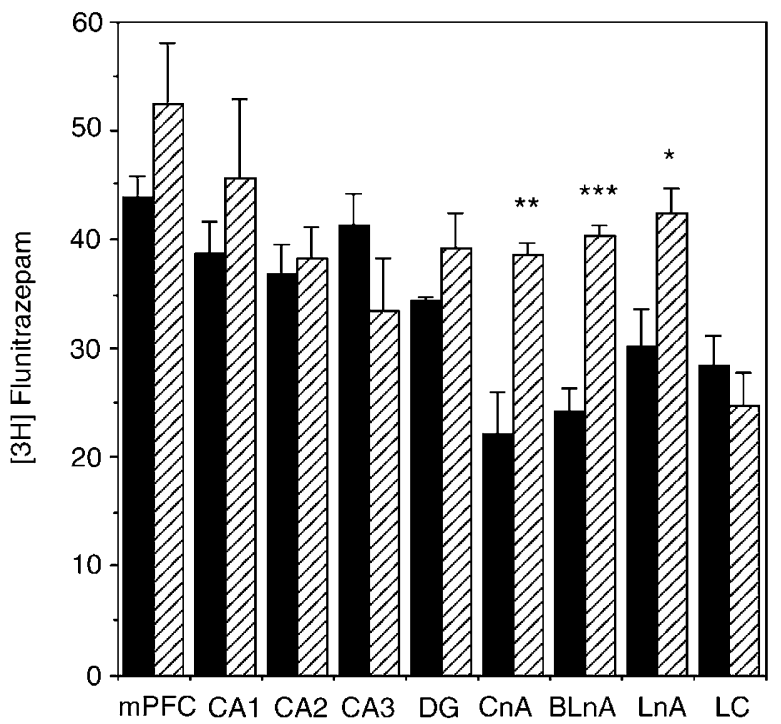

Figure I Mean $\pm S E M$ levels of central benzodiazepine receptor ( $\left[{ }^{3} \mathrm{H}\right]$ flunitrazepam) binding (in $\mathrm{fmol} / \mathrm{mg}$ protein) in various brain regions ( $n=6$ animals per group). mPFC, medial prefrontal cortex; DG, dentate gyrus; CAI-3, hippocampal Ammon's horn; BLnA, basolateral nucleus of the amygdala; LnA, lateral nucleus of the amygdala; $\mathrm{CnA}$, central nucleus of the amygdala; LC, locus coeruleus. $* * * * p<0.005$; $* * 2<0.0$ I; $* 2<0.05$.

coeruleus. $\left[{ }^{3} \mathrm{H}\right]$ flunitrazepam binding is nonselective. In order to examine the relevant receptor subtype, we examined the $\alpha 1$ subtype-selective BZ binding using $\left[{ }^{3} \mathrm{H}\right]$ zolpidem (Ruano et al, 1993). A significant Group$\times$ Region interaction effect $\left(\mathrm{F}_{(9,54)}=2.53 ; p<0.02\right)$ for $\left[{ }^{3} \mathrm{H}\right]$ zolpidem binding was observed (Figure 2). Post hoc analysis showed significantly increased $\alpha 1$ subtype-selective central BZ receptor levels in C57BL/6 mice in the central and lateral nuclei of the amygdala as well as the locus coeruleus. There were no significant group differences found in the medial prefrontal cortex, the hippocampus, and the basolateral nuclei of the amygdala.

\section{$\mathrm{GABA}_{\mathrm{A}}$ Subunit mRNA Expression}

There was a significant Group $\times$ Region interaction effect $\left(\mathrm{F}_{(9,54)}=4.55 ; \quad p<0.0002\right)$ for $\alpha 1$ mRNA expression (Figure 3a). Post hoc analysis revealed significantly increased $\alpha 1$ mRNA levels in C57BL/6 mice in the locus coeuruleus and decreased expression in the CA1 region of the hippocampus compared to $\mathrm{BALB} / \mathrm{c}$ mice. There were no significant group differences in the medial prefrontal cortex, the CA2, CA3, and dendate gyrus regions of the hippocampus or in the central, lateral, and basolateral nuclei of the amygdala. Analysis of the $\gamma 2$ mRNA data (Figure 3b) also showed a significant group and Group $\times$ Region interaction effect $\left(\mathrm{F}_{(9,54)}=5.28 ; p<0.0001\right)$. In this case however, $\gamma 2$ mRNA expression was significantly increased in the C57BL/6 mice in the central nucleus of the amygdala. No other comparisons approached significance.

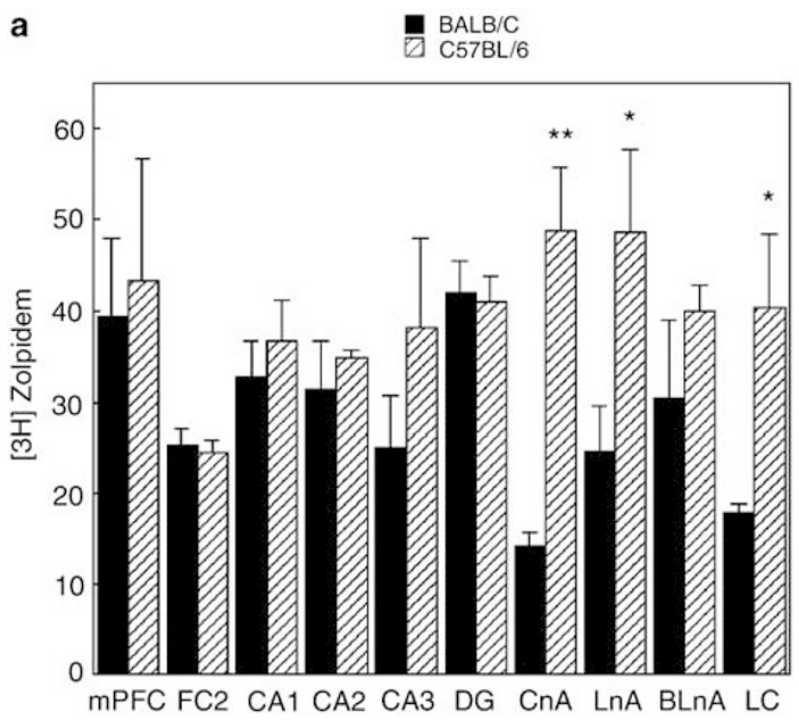

b

C57/BL6

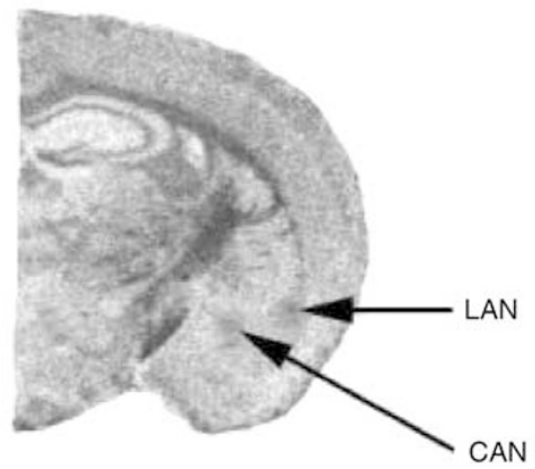

$\mathrm{Balb} / \mathrm{C}$

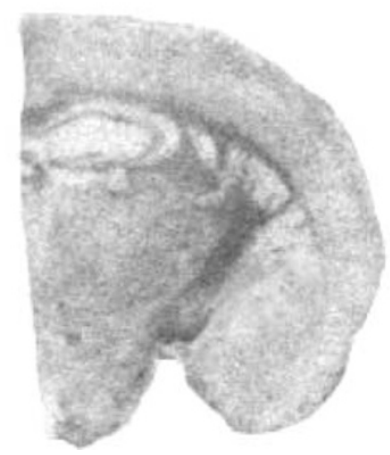

Figure 2 Mean \pm SEM levels of central benzodiazepine (type I) receptor $\left(\left[^{3} \mathrm{H}\right]\right.$ zolpidem) binding (in fmol/mg protein) in various brain regions $(n=6$ animals per group). [FC2], frontal cortex area 2; for other abbreviations, see the caption to Figure I. $* * * 00.005$; $* p<0.05$. (b) Representative photomicrograph depicting $\left[{ }^{3} \mathrm{H}\right]$ zolpidem binding in the central (CAN) and basolateral (BLN) nuclei of the amygdala in BALB/cBy] and C57BL/6By] mice.

\section{Adoption Study}

In the adoption study, we analyzed expression of the mRNAs for the $\gamma 2$ subunits in various brain regions. The results revealed a highly significant effect for rearing mother 
$\left(\mathrm{F}_{(1,16)}=60.9 ; \quad p<0.0001\right)$ but not biological mother $\left(\mathrm{F}_{(1,16)}=1.59 ; p=0.23\right.$; Figure 4$)$ in the central nucleus of the amygdala. There was no significant main effect of
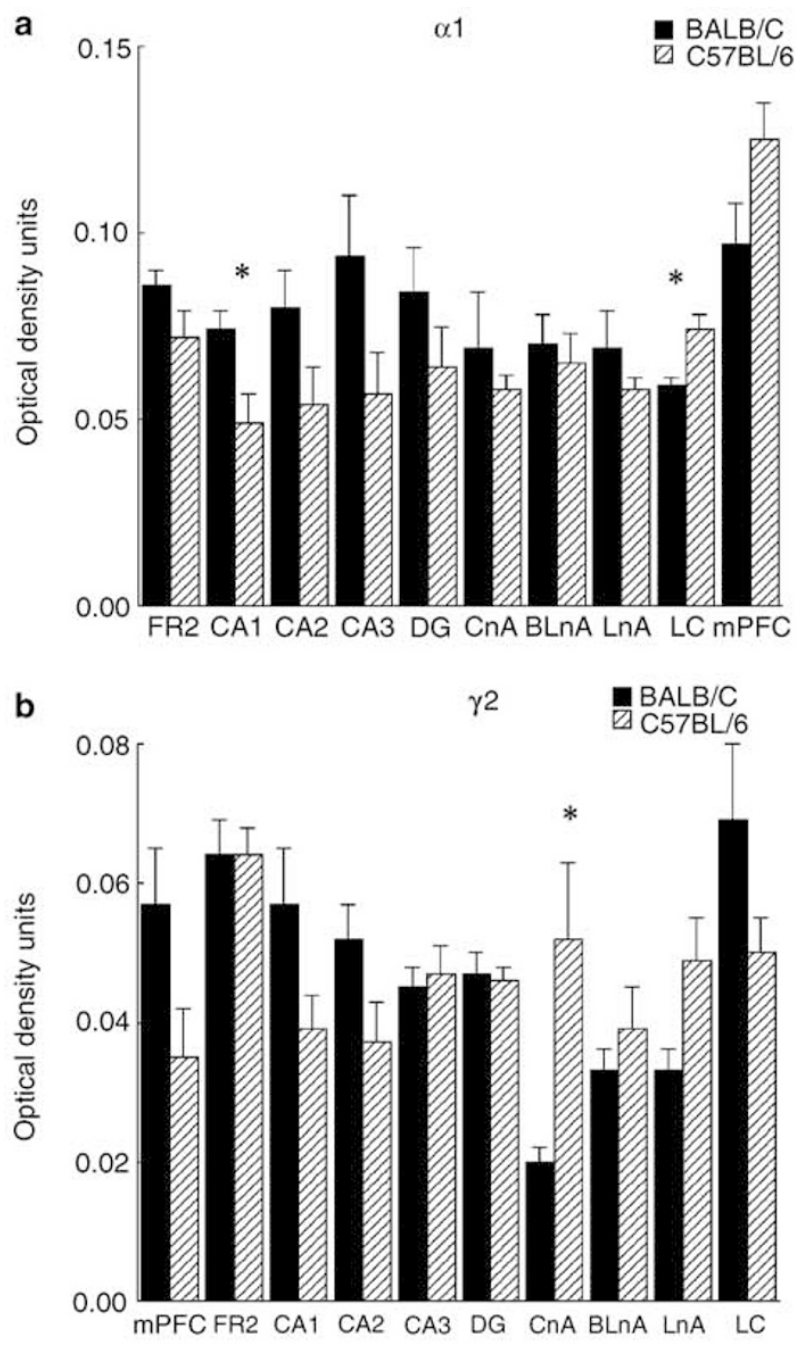

c

$$
\text { C57BL/6 }
$$

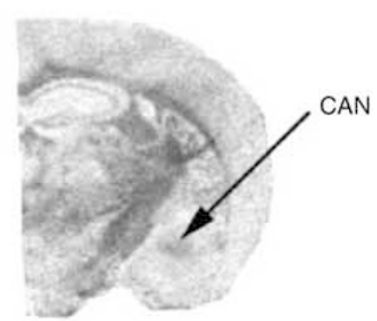

$\mathrm{Balb} / \mathrm{C}$

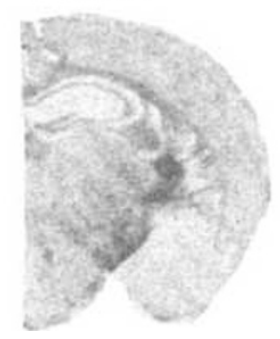

biological mother in any region examined. Thus, $\gamma 2$ subunit mRNA expression in animals born to $\mathrm{BALB} / \mathrm{c}$ mothers but reared by C57BL/ 6 dams was indistinguishable from that of the normal offspring of C57BL/6 mothers. The reverse was also true for pups born to C57BL/6 dams but reared by $\mathrm{BALB} / \mathrm{c}$ mothers.

\section{Behavioral Data}

Figure 5 shows the latency to place two legs on the table-top, and the latency to step fully (all four legs) off the platform and onto the table-top. The analysis of the latency to place two legs onto the table-top varied as a function of the Strain $\times$ Dam interaction $\left(\mathrm{F}_{(1,66)}=6.52 ; p=0.01\right)$. The post hoc tests indicated that the latencies to place two legs off the platform onto the table-top were longer in BALB/cByJ mice raised by a $\mathrm{BALB} / \mathrm{dam}$ than among $\mathrm{C} 57 \mathrm{BL} / \mathrm{cByJ}$ mice raised by either the same or a different strain. However, BALB/

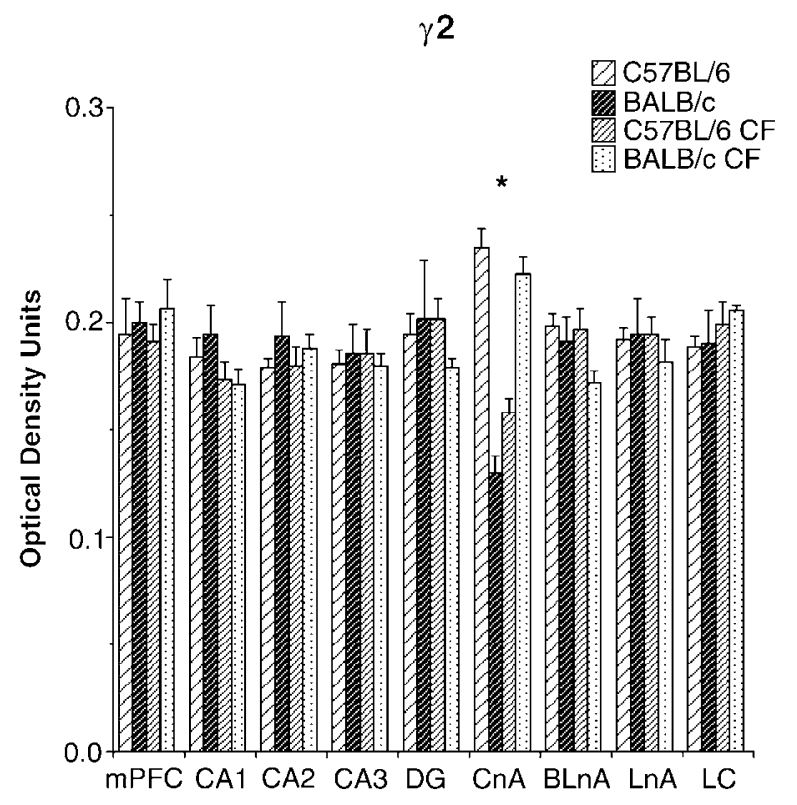

Figure 4 Mean \pm SEM levels of $m R N A$ for the $\gamma 2$ subunit of $G_{A B A}$ receptor in various brain regions expressed as optical density units from autoradiograms from in situ hybridization studies with ${ }^{35} \mathrm{~S}$-labelled oligonucleotide probes ( $n=5$ animals per group) in the biological offspring of $\mathrm{BALB} / \mathrm{C}$ mothers crossfostered to either BALB/C (B-B) or C57BL/6 (BC57) mothers and the biological offspring of $C 57 \mathrm{BL} / 6$ mothers crossfostered to either C57BL/6 (C57-C57) or BALB/C (C57-B) mothers. For abbreviations, see the caption to Figures I and $2 .{ }^{*} p<0.001$.

Figure 3 (a) Mean \pm SEM levels of mRNA for the $\alpha$ I subunit of GABA receptor in various brain regions expressed as optical density units from autoradiograms from in situ hybridization studies with ${ }^{35} \mathrm{~S}$-labelled oligonucleotide probes ( $n=6$ animals per group). ${ }^{*} p<0.05$. (b) Mean \pm SEM levels of mRNA for the $\gamma 2$ subunit of $G_{A B A}$ receptor in various brain regions expressed as optical density units from autoradiograms from in situ hybridization studies with ${ }^{35} \mathrm{~S}$-labelled oligonucleotide probes ( $n=6$ animals per group). ${ }^{*} p<0.05$. (c) Representative photomicrograph depicting the $\gamma 2$ subunit mRNA expression in the central (CAN) nucleus of the amygdala in BALB/cByJ and C57BL/6ByJ mice. For abbreviations, see the caption to Figures $I$ and 2. 

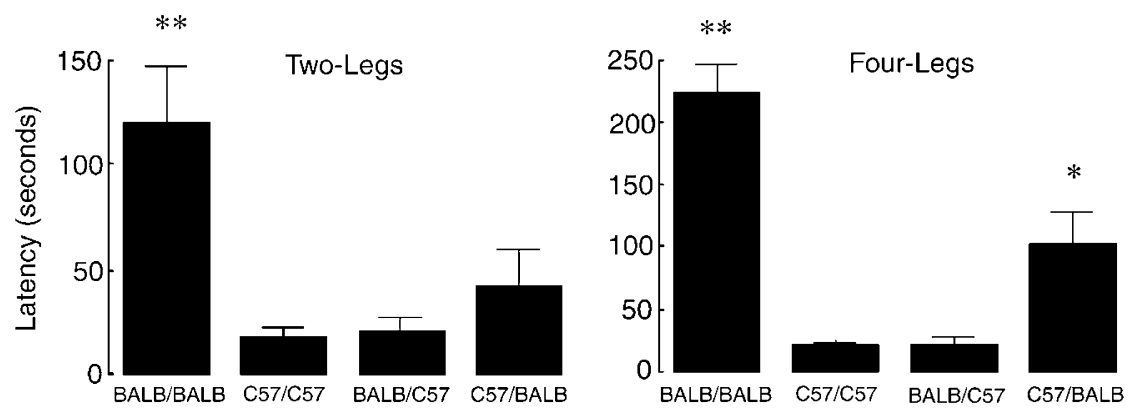

Figure 5 Mean \pm SEM latency of BALB/cByj mice raised by a BALB/cByJ $(n=14)$ or a C57BL/6By dam ( $n=16$; BALB/BALB and C57/BALB, respectively) or C57B/6By mice raised by the same strain $(n=19)$ or a BALB/CByJ $(n=21)$ dam (C57/C57 and C57/BALB, respectively). Mice were placed on a platform situated at the center of an open field and the latency to step down (with two or four legs) was measured. $* * p<0.00$ I; $* p<0.0$ I from all other groups.

cByJ mice raised by a C57BL/6ByJ dam exhibited latencies that did not differ from those of normal C57BL/6ByJ mice. The longer response latencies ordinarily evident in BALB/ cByJ were eliminated if these mice were raised with a C57BL/6ByJ dam. However, C57BL/6ByJ mice raised by a $\mathrm{BALB} / \mathrm{cByJ}$ dam showed no resemblance to the rearing, and instead were fully comparable to C57BL/6ByJ mice born to and reared by C57BL/6ByJ mothers. Latencies to place all four legs off the platform indicated that the response latencies were longer in $\mathrm{BALB} / \mathrm{cByJ}$ than in $\mathrm{C} 57 \mathrm{BL} / 6 \mathrm{ByJ}$ mice $\left(\mathrm{F}_{(1,66)}=95.58 ; p<0.01\right)$ and were also slower in mice raised by a BALB/cByJ than a C57BL/6ByJ dam $\left(\mathrm{F}_{(1,66)}=381 ; p<0.05\right)$. Post hoc analyses confirmed that the behavior of BALB/cByJ mice raised by a C57BL/6ByJ dam was intermediate between the two strains raised by the same strain dam (ie significantly lower than $\mathrm{BALB} / \mathrm{cByJ}$ mice reared by a $\mathrm{BALB} / \mathrm{cByJ}$ mother, and greater than in either group of $\mathrm{C} 57 \mathrm{BL} / 6 \mathrm{ByJ}$ animals).

\section{DISCUSSION}

$\mathrm{BALB} / \mathrm{c}$ mice show decreased levels of $\mathrm{BZ}$ binding in the central, lateral, and basolateral nuclei of the amygdala as measured by either $\left[{ }^{3} \mathrm{H}\right]$ flunitrazepam or $\left[{ }^{3} \mathrm{H}\right]$ zolpidem (Figures 1 and 2). Flunitrazepam is a nonselective ligand for the central BZ receptor. In contrast, zolpidem is highly selective for the $\alpha 1$ receptor subtype of the central BZ receptor. As in the previous studies, differences between $\mathrm{BALB} / \mathrm{c}$ and $\mathrm{C} 57 \mathrm{BL} / 6$ mice in BZ binding were highly specific to the amygdala (Hode et al, 2000). In this study, as in the previous research of Hode et al (2000), the most consistent differences in $\mathrm{BZ}$ binding emerged in the central nucleus of the amygdala. In the current study, this effect was most prominent using the $\alpha 1$ subtype-selective BZ receptor ligand zolpidem.

The $\alpha$ subunit forms the GABA binding site and it appears as though the interface between the $\alpha$ and $\gamma$ subunits forms the $\mathrm{BZ}$ receptor site. Thus, the presence of the $\gamma$ subunit is critical in defining the $\mathrm{BZ}$ site, which might explain the absence of direct overlap between the $\alpha 1$ mRNA expression and that of $\left[{ }^{3} \mathrm{H}\right]$ flunitrazepam binding. While the presence of the $\gamma$ subunits appears to define $\mathrm{BZ}$ receptor binding, it is the nature of the $\alpha$ subunit that determines the $\mathrm{BZ}$ receptor pharmacology (McKernan et al, 1991; Barnard et al, 1998; Mehta and Ticku, 1999). Receptors containing the $\alpha 1$ subunit exhibit a high affinity for zolpidem. However, expression of other $\alpha$ subunits, notably $\alpha 2, \alpha 3$, and $\alpha 5$, results in reduced affinity for zolpidem (McKernan et al, 1991; Barnard et al, 1998; Mehta and Ticku, 1999). The expression of the mRNAs for these subunits was not examined here. Moreover, immunoprecipitation assays are required to verify exactly which subunits are incorporated into functional $\mathrm{GABA}_{\mathrm{A}}$ receptor sites. The possibility of alterations in the $\alpha 5$ subunit will be especially interesting considering a recent report of the role of this subunit in fear conditioning (Bailey et al, 2002; Crestani et al, 2002).

$B Z$ receptor agonists exert anxiolytic effects via their actions at a number of limbic areas. However, the evidence so far is strongest at the level of amygdala complex (Pitkanen et al, 1997) comprising the lateral, basolateral, and the central nuclei of the amygdala. Direct administration of BZs into the basolateral or central nuclei of the amygdala results in an anxiolytic effect (Hodges et al, 1987; Pesold and Treit, 1995; Gonzalez et al, 1996). Recent studies have focused on the effects of intra-amygdaloid infusion of either $\mathrm{GABA}_{\mathrm{A}}$ or $\mathrm{BZ}$ receptor agonists or antagonists on fear conditioning. The results show potent effects of such treatments on the acquisition (amnesic effects) and expression (anxiolytic effects) of conditioned fear responses and underscore the importance of the amygdala as a critical target for the effects of $\mathrm{GABA}_{\mathrm{A}}$ and $\mathrm{BZ}$ receptor agonists (Brioni et al, 1989; Tomaz et al, 1993; Helmstetter and Bellgowan, 1994; Dickinson-Anson and McGaugh, 1997; Muller et al, 1997; Da Cunha et al, 1999). Hence, if one assumes the presence of an endogenous agonist (see $\mathrm{Da}$ Cunha et al, 1999), the differences in BZ binding might serve as a neural substrate for the increased fearfulness of the BALB/c strain.

The group differences in $\mathrm{BZ}$ binding in the central nucleus of the amygdala were associated with effects at the level of $\mathrm{GABA}_{\mathrm{A}}$ receptor subunit expression. The $\gamma 2$ subunit mRNA expression was significantly elevated in C57BL/6 mice compared to $\mathrm{BALB} / \mathrm{c}$ animals and, among the areas examined, differences were unique to the amygdala (see Figure $2 \mathrm{~b}$ ). Expression of the $\alpha 1$ subunit mRNA differed as a function of strain in the CA1 region of the hippocampus and the locus coeruleus; however, such differences did not map onto those in BZ binding. In contrast, the differences in $\gamma 2$ subunit expression could serve as a mechanism for the strain differences in $\mathrm{BZ}$ receptor binding in the central nucleus of the amygdala. The inclusion of a $\gamma 1$ or $\gamma 2$ subunit 
in the $\mathrm{GABA}_{\mathrm{A}}$ receptor complex appears to define the presence of a $\mathrm{BZ}$ receptor site. Point mutations have been identified within both subunits that are sufficient to eliminate BZ receptor binding (Amin et al, 1997; Buhr and Sigel, 1997; Buhr et al, 1997; Wingrove et al, 1997), and animals bearing a null mutation of the $\gamma 2$ subunit show approximately an $85 \%$ loss of $\left[{ }^{3} \mathrm{H}\right]$ flunitrazepam binding (Gunther et al, 1995).

These findings suggest that variations in maternal care might alter $\mathrm{GABA}_{\mathrm{A}}$ receptor subunit expression in the amygdala and thus $B Z / \mathrm{GABA}_{\mathrm{A}}$ receptor function. The results of the crossfostering study suggest a direct relationship between maternal care and individual differences in $\mathrm{GABA}_{\mathrm{A}}$ receptor subunit expression. Levels of $\gamma 2$ subunit mRNA in animals born to BALB/c mothers but reared by C57BL/6 dams were indistinguishable from that of the normal offspring of C57BL/6 mothers. The reverse was also true for pups born to $\mathrm{C} 57 \mathrm{BL} / 6$ dams but reared by BALB/C mothers. These findings imply a postnatal, maternal effect on $\mathrm{GABA}_{\mathrm{A}}$ receptor development in these mice strains and are consistent with previous crossfostering studies examining behavioral outcomes in these strains (Zaharia et al, 1996). Moreover, fear-related behavior in $\mathrm{BALB} / \mathrm{c}$ mice is altered by postnatal handling, which is known to increase maternal licking/grooming (Lee and Williams, 1975; Liu et al, 1997).

As previously reported (Anisman et al, 2001; Belzung and Griebel, 2001; Beuzen and Belzung, 1995; Oliverio et al, 1973; Peeler and Nowakowski, 1987), BALB/cByJ mice exhibited greater anxiety-like behavior relative to $\mathrm{C} 57 \mathrm{BL} /$ $6 \mathrm{ByJ}$ mice upon testing in the step-down exploration task. We (Zaharia et al, 1996) previously reported that the poor performance of $\mathrm{BALB} / \mathrm{cByJ}$ mice in a Morris water-maze spatial learning test, which is subject to modification by anxiolytic treatment, is affected by the strain of the rearing mother. In contrast, the more proficient Morris water-maze performance of the less fearful C57BL/6ByJ was not altered by the strain of the rearing dam. Similarly, in the present investigation, when $\mathrm{BALB} / \mathrm{cByJ}$ mice were crossfostered onto a $\mathrm{C} 57 \mathrm{BL} / 6 \mathrm{ByJ}$ dam, the anxiety responses characteristic of BALB/cByJ mice were largely attenuated. However, among $\mathrm{C} 57 \mathrm{BL} / 6 \mathrm{ByJ}$ mice, the relatively low levels of anxiety ordinarily evident were not increased when mice of this strain were reared by a BALB/CByJ dam. The epigenetic effects of postnatal, crossfostering apparent in the BALB/ cByJ mice may in fact occur in C57BL/6ByJ mice, but over different time periods. Francis et al (2003) found that C57BL/6ByJ mice fostered to BALB/cByJ dam over both the prenatal period (with transplantation of $\mathrm{C} 57 \mathrm{BL} / 6 \mathrm{ByJ}$ embryos into BALB/cByJ mothers) and the postnatal period (with crossfostering identical to our procedure) did indeed resemble normal $\mathrm{BALB} / \mathrm{cByJ}$ on measures of open-field exploration, Morris water-maze learning, plus maze behavior, and prepulse inhibition. However, this effect occurred only if the BALB/cByJ maternal environment prevailed both pre- and postnatally. Similar to our findings, the C57BL/ $6 \mathrm{ByJ}$ mice crossfostered to BALB/cByJ dams after delivery from $B A L B / c B y J$ mothers were unaffected. In this study and others (Zaharia et al, 1996), BALB/cByJ mice fostered postnatally to $\mathrm{C} 57 \mathrm{BL} / 6 \mathrm{ByJ}$ mothers did indeed resemble C57BL/6ByJ mice on behavioral measures of fear. These studies possibly reflect a fascinating genomic constraint on the effect of environmental influence, and its timing, on phenotype.

The behavioral data also reveal some dissociation between $\mathrm{GABA}_{\mathrm{A}}$ receptor subunit expression in the amygdala and fear behavior. However, in the current study, we examined only the $\alpha 1$ and $\gamma 2$ subunits. $\mathrm{GABA}_{\mathrm{A}}$ receptor function is determined through a substantially greater range of subunits, including the $\alpha 5$ subunit that has been linked to fear conditioning (Bailey et al, 2002; Crestani et al, 2002). Moreover, the expression of such complex behavioral patterns will inevitably involve a diverse neural circuitry of which the amygdaloid $\mathrm{GABA}_{\mathrm{A}}$ receptor is but one component. It is interesting, however, that unlike the behavioral findings, the expression of mRNA encoding for the $\gamma 2$ subunit was altered in $\mathrm{C} 57 \mathrm{BL} / 6 \mathrm{ByJ}$ reared by BALB/ cByJ mothers during the postnatal period. Obviously, individual features of phenotype will emerge in response to differing gene $\times$ environment interactions at different stages in development.

Strain differences in mice are commonly assumed to reflect genomic variation. While this is undoubtedly true, the relationship between genotype and phenotype is less obvious than often thought. Simply put, the existence of strain differences in any specific trait does not imply that such variation in phenotype is directly and invariably linked to differences in genotype. Certainly, one possibility is that differences in maternal behavior might be directly associated with genomic variation, and that the differences in $\mathrm{BZ} / \mathrm{GABA}_{\mathrm{A}}$ receptor development and behavioral fearfulness might then emerge as a function of altered maternal care, and not as a direct effect of genomic variation on fearfulness. Such maternally mediated, indirect genetic effects are considered common in evolutionary biology (eg Hunt and Simmons, 2002 and references therein). Such effects are thought to form the basis whereby traits without heritable variation can evolve because of the inheritable environmental variation provided through indirect genetic effects. In this case, the inheritable environmental variation is that of strain differences in maternal care. Of course, the differences in maternal behavior could also be secondary to some other trait, and so on. The critical question concerns the mechanisms by which genomic factors result in phenotypic variation, and this will no doubt involve a series of complex gene $\times$ environment interactions.

There are certainly implications for human studies attempting to quantify genetic and environmental contributions to individual differences. While the importance of gene $\times$ environment interactions is often considered, research commonly relies on linear regression models that provide estimates of the strength of association between input factors and defined outcomes. Such measures largely focus on 'main effects' estimating the percentage of the variance accounted for by 'genetic' $v s$ 'environmental' factors. In the case of the behavioral differences between $\mathrm{BALB} / \mathrm{c}$ and $\mathrm{C} 57 \mathrm{BL} / 6$ mice, information on the strain of the animals would be sufficient to distinguish statistically one group from the other, as virtually almost $\mathrm{BALB} / \mathrm{c}$ mice behave differently than do C57BL/6 animals on tests of fearfulness or learning/memory. Knowledge of differences in the postnatal environment, such as variations in maternal behavior, would add absolutely nothing to the ability of the equation to predict differences in behavior. A linear 
regression analysis of variation in, say, timidity would yield no insight whatsoever into the potential importance of environmental factors - partitioning of the variance would slide entirely onto the so-called 'genetic' variation reflected in the identification of the strain, despite the fact that the maternal styles of these strains are markedly different from one another. Although the addition of the environmental variables ought to increase the predictive value, within a linear model these variables would be considered statistically unimportant (or redundant) in determining the variance associated with phenotype. Hence we might be tempted to conclude that the differences in fearfulness emerge largely, if not exclusively, from genetic factors. Precisely, this form of interpretation has given rise to such remarkably specious debates as to 'whether parents really matter?' In the case of the BALB/c and C57BL/6 mice, there is considerable phenotypic plasticity such that maternal care does indeed alter behavioral responses to stress and $\mathrm{BZ} / \mathrm{GABA}_{\mathrm{A}}$ receptor development in brain regions that mediate the expression of fearfulness. For these animals, parents do matter. It is tempting to think that, in this case, the effects of genomic variation are mediated by strain differences in maternal care, thus blurring considerably the distinction between gene and environment. Given that phenotypic expression across strains of mice is influenced by test conditions, even using standardized procedures (Crabbe et al, 1999; Wahlsten et al, 2003), it should not be surprising to find that profound behavioral experiences, especially those encountered early in life, would impact on emotionality and on the presumed neurochemical substrates for anxiety-like states.

\section{ACKNOWLEDGEMENTS}

This research was supported by grants from the Canadian Institutes of Health Research to MJM and to HA. CC is a graduate fellow and a recipient of a Canadian Institutes of Health Research Doctoral Research Award. MJM holds a Senior Investigator award from the Canadian Institutes of Health Research and is a Lieber Investigator of the National Alliance for Research in Schizophrenia and Affective Disorders. HA holds a Canada Research Chair award.

\section{REFERENCES}

Amin J, Brooks-Kayal A, Weiss DS (1997). Two tyrosine residues on the alpha subunit are crucial for benzodiazepine binding and allosteric modulation of gamma-aminobutyric acidA receptors. Mol Pharmacol 51: 833-841.

Anisman H, Hayley S, Kelly O, Borowski T, Merali Z (2001). Psychogenic, neurogenic, and systemic stressor effects on plasma corticosterone and behavior: mouse strain-dependent outcomes. Behav Neurosci 115: 443-454.

Bailey DJ, Tetzlaff JE, Cook JM, He X, Helmstetter FJ (2002). Effects of hippocampal injections of a novel ligand selective for the alpha 5 beta 2 gamma 2 subunits of the GABA/benzodiazepine receptor on Pavlovian conditioning. Neurobiol Learn Memory 78: $1-10$.

Barnard EA, Darlison MG, Fujita N, Glencorse TA, Levitan ES, Reale $\mathrm{V}$ et al (1988). Molecular biology of the GABAA receptor. Adv Exp Med Biol 236: 31-45.
Barnard EA, Skolnick P, Olsen RW, Mohler H, Sieghart W, Biggio $\mathrm{G}$ et al (1998). International Union of Pharmacology. XV. Subtypes of gamma-aminobutyric acidA receptors: classification on the basis of subunit structure and receptor function. Pharmacol Rev 50: 291-313.

Belzung C, Griebel G (2001). Measuring normal and pathological anxiety-like behaviour in mice: a review. Behav Brain Res 125: 141-149.

Beuzen A, Belzung C (1995). Link between emotional memory and anxiety states: a study by principal component analysis. Physiol Behav 58: 111-118.

Brioni JD, Nagahara AH, McGaugh JL (1989). Involvement of the amygdala GABAergic system in the modulation of memory storage. Brain Res 487: 105-112.

Buhr A, Schaerer MT, Baur R, Sigel E (1997). Residues at positions 206 and 209 of the alphal subunit of gamma-aminobutyric acid A receptors influence affinities for benzodiazepine binding site ligands. Mol Pharmacol 5: 676-682.

Buhr A, Sigel E (1997). A point mutation in the gamma2 subunit of gamma-aminobutyric acid type A receptors results in altered benzodiazepine binding site specificity. Proc Natl Acad Sci USA 94: 8824-8829.

Bureau MH, Olsen RW (1993). GABA $\mathrm{A}$ receptor subtypes: ligand binding heterogeneity demonstrated by photoaffinity labeling and autoradiography. Neurochemistry 61: 1479-1491.

Caldji C, Diorio J, Meaney MJ (2003). Variations in maternal care alter $\mathrm{GABA}_{\mathrm{A}}$ receptor subunit expression in brain regions associated with fear. Neuropsychopharmacology 28: 1950-1959.

Caldji C, Francis D, Sharma S, Plotsky PM, Meaney MJ (2000). The effects of early rearing environment on the development of $\mathrm{GABA}_{\mathrm{A}}$ and central benzodiazepine receptor levels and noveltyinduced fearfulness in the rat. Neuropsychopharmacology 22: 219-229.

Caldji C, Tannenbaum B, Sharma S, Francis DD, Plotsky PM, Meaney MJ (1998). Maternal care during infancy regulates the development of neural systems mediating the expression of behavioral fearfulness in adulthood in the rat. Proc Natl Acad Sci USA 95: 5335-5340.

Chapoutier G, Bondoux D, Martin B, Desforges C (1991). Genetic difference in sensitivity to B-carbolines: evidence for the involvement of brain benzodiazepine receptors. Brain Res 553: 342-346.

Crabbe JC, Wahlsten D, Dudek BC (1999). Genetics of mouse behavior: interactions with laboratory environment. Science 4: 1670-1672.

Crestani F, Keist R, Fritschy JM, Benke D, Vogt K, Prut L et al (2002). Trace fear conditioning involves hippocampal alpha5 GABA(A) receptors. Proc Natl Acad Sci USA 99: 8980-8985.

Da Cunha C, Roozendaal B, Vazdarjanova A, McGaugh JL (1999). Microinfusions of flumazenil into the basolateral but not the central nucleus of the amygdala enhance memory consolidation in rats. Neurobiol Learn Memory 72: 1-7.

Desforges C, Venault P, Dodd R, Chapouthier G, Roubertoux PL (1989). B-carboline-induced seizure in mice: genetic analysis. Pharmacol Biochem Behav 34: 733-737.

Dickinson-Anson H, McGaugh JL (1997). Bicuculline administered into the amygdala after training blocks benzodiazepine-induced amnesia. Brain Res 752: 197-202.

Francis DD, Diorio J, Liu D, Meaney MJ (1999). Nongenomic transmission across generations in maternal behavior and stress responses in the rat. Science 286: 1155-1158.

Francis DD, Diorio J, Plotsky PM, Meaney MJ (2002). Environmental enrichment reverses the effects of maternal separation on stress reactivity. J Neurosci 22: 7840-7843.

Francis DD, Szegda K, Campbell G, Martin WD, Insel TR (2003). Epigenetic sources of behavioral differences in mice. Nature (Neurosci) 6: 445-446. 
Franklin KBJ, Paxinos G (1997). The Mouse Brain in Stereotaxic Coordinates. Plenum: San Diego.

Gonzalez LE, Andrews N, File SE (1996). 5-HT1A and benzodiazepine receptors in the basolateral amygdala modulate anxiety in the social interaction test, but not in the elevated plus-maze. Brain Res 732: 145-153.

Gorman JM, Kent JM, Sullivan GM, Coplan JD (2000). Neuroanatomical hypothesis of panic disorder, revised. Am J Psychiatry 157: 493-505.

Griebel G, Belzung C, Misslin R, Vogel E (1993). The freeexploratory paradigm: an effective method for measuring neophobic behavior in mice and testing potential neophobicreducing drugs. Behav Pharmacol 4: 637-644.

Gunther U, Benson J, Benke D, Fritschy JM, Reyes G, Knoflach F et al (1995). Benzodiazepine-insensitive mice generated by targeted disruption of the gamma 2 subunit gene of gammaaminobutyric acid type A receptors. Proc Natl Acad Sci USA 92: 7749-7753.

Helmstetter FJ, Bellgowan PS (1994). Effects of muscimol applied to the basolateral amygdala on acquisition and expression of contextual fear conditioning in rats. Behav Neurosci 108: 1005-1009.

Hode Y, Ratomponirina S, Gobaille M, Kopp C, Misslin R (2000). Hypoexpression of benzodiazepine receptors in the amygdala of neophobic BALB/C mice compared to C57BL/6 mice. Pharmacol Biochem Behav 1: 35-38.

Hodges H, Green S, Glenn B (1987). Evidence that the amygdala is involved in benzodiazepine and serotonergic effects on punished responding, but not discrimination. Psychopharmacology 92 491-504.

Hunt J, Simmons LW (2002). The genetics of maternal care: direct and indirect genetic effects on phenotype in the dung beetle Onthophagus taurus. Proc Natl Acad Sci USA 99: $6828-6832$.

Lee MH, Williams DI (1975). Long term changes in nest condition and pup grouping following handling of rat litters. Dev Psychobiol 8: 91-95.

Lindzey G, Thiessen D (eds) (1970). Contributions to BehaviorGenetic Analysis. The Mouse as a Prototype. Appleton-CenturyGrafts, Educational Division/Meredith Corporation: New York.

Liu D, Tannenbaum B, Caldji C, Francis DD, Freedman A, Sharma $S$ et al (1997). Maternal care, hippocampal glucocorticoid receptor gene expression and hypothalamic-pituitary-adrenal responses to stress. Science 277: 1659-1662.

Maccari S, Piazza PV, Kabbaj M, Barbazanges A, Simon H, LeMoal $M$ (1995). Adoption reverses the long-term impairment in glucocorticoid feedback induced by prenatal stress. J Neurosci 15: $110-116$.

McKernan RM, Quirk K, Prince R, Cox PA, Gillard NP, Ragan CI et al (1991). $\mathrm{GABA}_{\mathrm{A}}$ receptor subtypes immunopurified from rat brain with alpha subunit-specific antibodies have unique pharmacological properties. Neuron 4: 667-676.

McKernan RM, Whiting PJ (1997). Which $\mathrm{GABA}_{\mathrm{A}}$-receptor subtypes really occur in the brain? Trends Neurosci 19: 139-143.

Mehta AK, Ticku MK (1999). An update on $\mathrm{GABA}_{\mathrm{A}}$ receptors. Brain Res Rev 29: 196-217.
Mihic SJ, Van Berckel BN, O’Dowd BF, Nguyen T, Wu PH (1992). Effects of sedatives on GABA-mediated chloride flux into cerebral cortical microsacs prepared from emotional and nonemotional mice. Eur J Pharmacol 218: 283-286.

Muller J, Corodimas KP, Fridel Z, LeDoux JE (1997). Functional inactivation of the lateral and basal nuclei of the amygdala by muscimol infusion prevents fear conditioning to an explicit conditioned stimulus and to contextual stimuli. Behav Neurosci 111: 683-691.

Oliverio A, Eleftheriou RS, Bailey DW (1973). A gene influencing active performance in mice. Physiol Behav 11: 497-501.

Peeler DF, Nowakowski RS (1987). Genetic factors and the measurement of exploratory activity. Behav Neural Biol 48: 90-103.

Pesold C, Treit D (1995). The central and basolateral amygdala differentially mediate the anxiolytic effects of benzodiazepines. Brain Res 671: 213-221.

Pitkanen A, Savander V, LeDoux JE (1997). Organization of intraamygdaloid circuitries in the rat: an emerging framework for understanding functions of the amygdala. Trends Neurosci 20: 517-523.

Robertson HA (1979). Benzodiazepine receptors in 'emotional' and 'non-emotional' mice; comparison of four strains. Eur J Pharmacol 56: 163-166.

Rosen JB, Shulkin J (1998). From normal fear to pathological anxiety. Psychol Rev 105: 325-350.

Ruano D, Benavides J, Machlo A, Vitorica J (1993). Regional differences in the enhancement by GABA of $\left[{ }^{3} \mathrm{H}\right]$ zolpidem binding to $\mathrm{w} 1$ sites in rat membranes and sections. Brain Res 600: $134-400$.

Sakic B, Szechtman H, Talangbayan H, Denburg SD, Carbotte RM, Denburg JA (1994). Disturbed emotionality in autoimmune MRL-lpr mice. Physiol Behav 56: 609-617.

Sieghart W (1995). Structure and pharmacology of gammaaminobutyric acidA receptor subtypes. Pharmacol Rev 47: 181-234.

Tomaz C, Dickinson-Anson H, McGaugh JL, Souza-Silva MA, Viana MB, Graeff FG (1993). Localization in the amygdala of the amnestic action of diazepam on emotional memory. Behav Brain Res 58: 99-105.

Wahlsten D, Metten P, Phillips TJ, Boehm II SL, Burkhart-Kasch S, Dorow J et al (2003). Different data from different labs: lessons from studies of gene-environment interaction. J Neurobiol 54: 283-311.

Wingrove PB, Thompson SA, Wafford KA, Whiting PJ (1997). Key amino acids in the gamma subunit of the gamma-aminobutyric acidA receptor that determine ligand binding and modulation at the benzodiazepine site. Mol Pharmacol 52: 874-881.

Wisden W, Laurie DJ, Monyer H, Seeburg PH (1992). The distribution of $13 \mathrm{GABA}_{\mathrm{A}}$ receptor subunit mRNAs in the rat brain. 1. Telencephalon, diencephalon, mesencephalon. J Neurosci 12: 1040-1062.

Zaharia MD, Kulczycki J, Shanks N, Meaney MJ, Anisman H (1996). The effects of early post-natal stimulation of Morris water-maze acquisition in adult mice: genetic and maternal factors. Psychopharmacology 128: 227-239. 